\title{
Interruptions and nursing workload during medication administration process
}

\author{
Interrupções e carga de trabalho de enfermagem durante a administração de medicamentos \\ Interrupciones y carga de trabajo de enfermería durante la administración de medicamentos
}

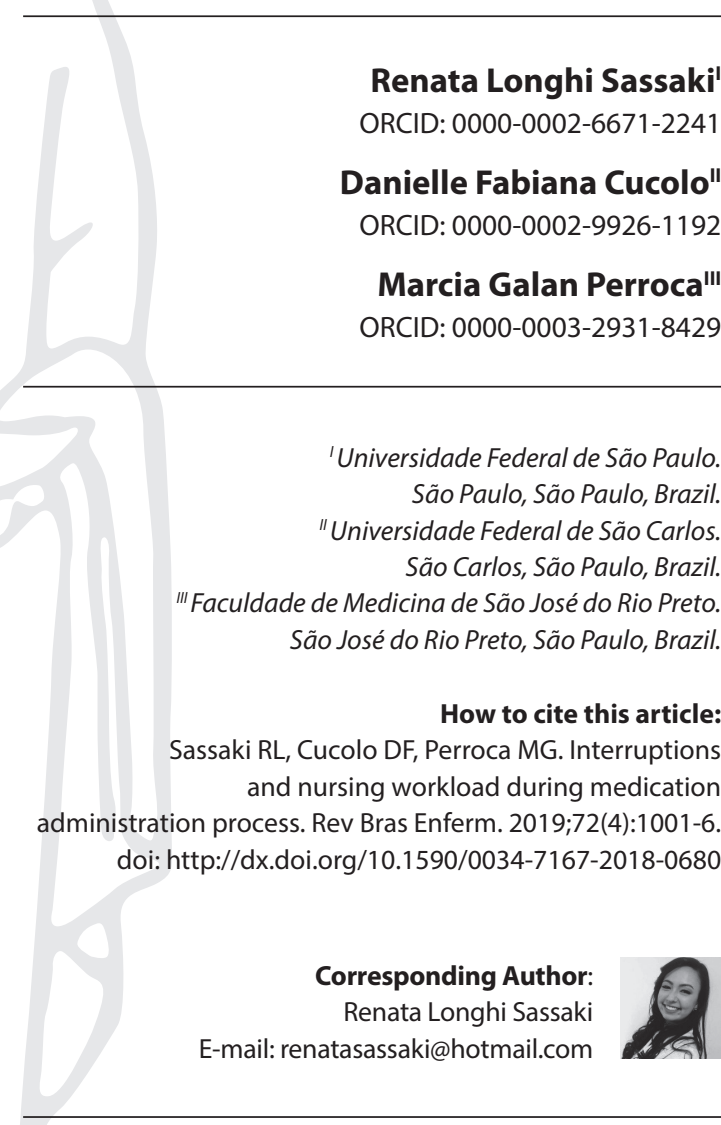

Submission: 08-17-2018 Approval: 10-28-2018

\begin{abstract}
Objective: To investigate the sources and causes of interruptions during the medication administration process performed by a nursing team and measure its frequency, duration and impact on the team's workload. Métodos: This is an observational study that timed 121 medication rounds (preparation, administration and documentation) performed by 15 nurses and nine nursing technicians in a Neonatal Intensive Care Unit in the countryside of the state of São Paulo. Resultados: 63 (52.1\%) interruptions were observed. In each round, the number of interruptions that happened ranged from 1-7, for 127 in total; these occurred mainly during the preparation phase, $97(76.4 \%)$. The main interruption sources were: nursing staff - $48(37.8 \%)$ - and self-interruptions $-29(22.8 \%)$. The main causes were: information exchanges - 54 (42.5\%) - and parallel conversations - 28 (22\%). The increase in the mean time ranged from 53.7 to $64.3 \%$ (preparation) and from 18.3 to $19.2 \%$ (administration) $-p \leq 0.05$. Conclusão: Interruptions in the medication process are frequent, interfere in the workload of the nursing team and may reflect on the safety of care.

Descriptors: Workload; Time Management; Workflow; Nursing Care; Patient Safety.
\end{abstract}

\section{RESUMO}

Objetivo: Investigar fontes e causas das interrupções durante o processo de administração de medicamentos realizado pela equipe de enfermagem e mensurar sua frequência, duração e impacto sobre a carga de trabalho. Métodos: Observacional com tempos cronometrados durante 121 rodadas de medicação (preparo, administração e documentação) realizadas por 15 enfermeiros e nove técnicos de enfermagem em Unidade de Terapia Intensiva Neonatal no interior de São Paulo. Resultados: Foram observadas 63 (52,1\%) interrupções. Em cada rodada, ocorreram de 1-7totalizando 127, principalmente na fase de preparo, 97 $(76,4 \%)$. As principais fontes constituíram-se em: equipe de enfermagem - $48(37,8 \%)$ - e autointerrupções - 29(22,8\%). Já as principais causas: troca de informações - $54(42,5 \%)$ - e conversa paralela - 28 (22\%). O aumento do tempo médio variou de 53,7 a 64,3\% (preparo) e de 18,3 a 19,2\% (administração) $p \leq 0,05$. Conclusão: Interrupções no processo medicamentoso são frequentes, interferem na carga de trabalho da enfermagem e podem refletir na segurança do cuidado.

Descritores: Carga de Trabalho; Gerenciamento do Tempo; Fluxo de Trabalho; Cuidados de Enfermagem; Segurança do Paciente.

\section{RESUMEN}

Objetivo: Examinar las fuentes y las causas de interrupciones durante el proceso de administración de medicamentos realizado por el personal de enfermería y también medir su frecuencia, duración e impacto sobre la carga de trabajo de estos. Métodos: Estudio observacional con tiempos cronometrados durante 121 rondas de medicación (preparación, administración y documentación) realizadas por 15 enfermeros y 9 técnicos de enfermería en una Unidad de Cuidado Intensivo Neonatal en el interior de São Paulo. Resultados: Se observaron 63 (52,1\%) interrupciones. En cada ronda, ocurrieron de 1-7, totalizando 127, principalmente en la fase de preparación, 97 (76,4\%). Las principales fuentes fueron: el personal de enfermería $-48(37,8 \%)-$, y las autointerrupciones -29 (22,8\%)-. Ya las principales causas fueron: el intercambio de información -54 (42,5\%)- y la conversación paralela -28 (22\%)-. El incremento del promedio del tiempo varió del $53,7 \%$ al $64,3 \%$ (preparación) y del 18,3\% al 19,2\% (administración) p $\leq 0,05$. Conclusión: Las interrupciones en el proceso medicamentoso son frecuentes, interfieren en la carga de trabajo de la enfermería y pueden comprometer la seguridad del cuidado.

Descriptores: Carga de Trabajo; Administración del Tiempo; Flujo de Trabajo; Atención de Enfermería; Seguridad del Paciente. 


\section{INTRODUCTION}

Interruptions are the occurrence of external events capable of diverting attention, leading to the break of continuity of an activity $^{(1)}$. They are frequent during the workflow of nursing teams $s^{(2)}$ and have been identified as one of the main causes of medication errors ${ }^{(3-4)}$.

Nurses rarely conclude an activity without interruptions ${ }^{(5)}$. Studies report the occurrence of approximately 26 interruptions per hour ${ }^{(6)}$, with the consequent increase in the time spent on activities $^{(7)}$. Interruptions thus cause greater stress and increase the mental work of nurses, and may affect their performance ${ }^{(6,8)}$.

Usually, its sources cover the nursing staff(1,4,8-9), patient and family members and other health professionals ${ }^{(10)}$. Among its causes, requests made by team itself $f^{(4)}$, the care needs of patients and the provision of material resources ${ }^{(10)}$ can be cited. Sources and causes may present different characteristics depending on the observed unit ${ }^{(10)}$.

Patient safety may be affected by interruptions ${ }^{(3,11-12)}$. Concentration is crucial to minimize distractions and errors during care activities ${ }^{(10)}$. Safe practice has been considered an international issue and addressed as a relevant factor for the quality of care, especially with regard to the safe administration of medicines ${ }^{(13-14)}$. The medication process is considered complex, having impacts on the workload of nursing teams ${ }^{(11,14)}$ and may lead to errors ${ }^{(14)}$. Nursing professionals have been reported to double the medication dose during the preparation phase due to interruptions in their workflow ${ }^{(15)}$.

Although international studies have described the impact of interruptions in clinical practice and patient safety ${ }^{(2-4,8-9,15)}$, Brazilian studies on this topic are still scarce. Studies that can be highlighted are a literature review on interruption as a detrimental factor to patient safety ${ }^{(13)}$; the mapping of interruptions in Intensive Care Units (ICU) ${ }^{(16)}$; and interruptions and their implications in the professional practice environment as perceived by nurses ${ }^{(17)}$.

This study chose a Neonatal ICU (NICU) as the field of study due to its particularities regarding drug therapy ${ }^{(18)}$. The types of drugs used and the high chance of making a calculation error during the preparation of medications increases the occurrence of adverse events ${ }^{(18)}$, especially in the presence of interruptions.

This study sought to deepen the understanding of the phenomenon by stratifying in the different phases of medication rounds regarding the measured time and the impact on the workload. To this end, this investigation sought to answer the following questions: When, how and with what frequency interruptions occur during the process of preparation, administration and documentation of medication? What is the duration of the interruption process and what is its impact on the workload of the nursing team?

\section{OBJECTIVES}

To investigate the sources and causes of interruptions during the medication administration process performed by the nursing team of a NICU and to measure the frequency, duration and the impact of interruptions on the workload of the team.

\section{METHODS}

\section{Ethical aspects}

This study received a favorable opinion from the appropriate Research Ethics Committee of the School of Medicine of São José do Rio Preto. Nurses and nursing technicians were informed about the study objectives and that their participation was voluntary. All professionals received informed consent forms prior to the observation.

\section{Study design, location and period}

This is a cross-sectional descriptive study using the observational method and conducted in the NICU of an extra-capacity teaching hospital located in the countryside of the state of São Paulo, Brazil. Data were collected from December 2016 to January 2017.

\section{Sample: inclusion and exclusion criteria}

The sample was chosen by convenience of 121 rounds of medication administration performed by 15 nurses (morning=7; afternoon=8) and nine nursing technicians (morning=5; afternoon=4) assigned to the unit during the investigation period. Each medication round consisted of the phases of preparation, administration and documentation of each patient. A Canadian study on this topic determined a sample size of 100 rounds, based on previous studies and considering a 0.05 significance level and 0.8 power $^{(9)}$.

\section{Study protocol}

Two instruments were used to obtain the information. The first instrument contemplated the professional profile (time of performance, position and function, work shift, and professional qualification considering the highest level completed) including gender and age. This instrument was applied only once. The second instrument was constructed from causes and sources found in the literature ${ }^{(4,10,16-17)}$, and was previously tested in the studied unit in three different moments. This instrument was applied during the observation sessions. Its application enabled the identification of interruptions in each phase of the medication process (preparation, administration and documentation). Researchers recorded the frequency, time spent, sources (patients, companions, nursing team, multidisciplinary team, self-interruption and support services) and the causes of interruption by a professional during the round of medication, which were classified as:

- Unforeseen and emergency needs related to the patient's well-being;

- Supply of materials: forgetting materials, needing to replenish material on the medication carts, searching for missing medication in another unit;

- Information exchange: communication between the teams about patient-related issues and services;

- Educational demand: companions asking the team for information and guidance about the patient;

- Aid to the nursing team: varied aid, double-checking; 
- Alarms: infusion pumps, mechanical ventilators, incubators and monitors;

- Parallel Conversation: conversation not related to the patient and to the procedure.

The measured time technique ${ }^{(19)}$ was used to map the interruptions during the process of medication. The technique allowed the sequence and detailed workflow of short-duration activities to be recorded ${ }^{(5)}$. The timer was started at every continuity break during the activity and stopped when it ended, being reset to zero; this process was repeated for every interruption. The sources and causes of the interruption were also recorded, as well as at which phase of the medication round it happened (preparation, administration, or documentation).

The nursing team was observed by one of the researchers during the morning and afternoon shifts, Monday through Friday, being accompanied by a professional during each shift and round of medication. There was no availability for observation during the night shift.

\section{Analysis of results and statistics}

The findings were analyzed using the Stats Direct Statistical Software version 1, 9, 15 (05/05/2002) and SPSS version 24 (2014), with the significance level established in $p \leq 0.05$. Frequency, percentage, mean and standard deviation (SD) were calculated in the descriptive analysis. Kruskal Wallis and Mann-Whitney tests were applied to assess the significance between the durations of the medication processes. To measure the impact of interruptions on the team's workload, the time of rounds of medication in each of the phases (preparation, administration and documentation) without and with interruptions was measured, and the mean time of each was calculated.

\section{RESULTS}

The participating nurses presented 29.5 years as the mean age ( $S D=4.5$; variation from 24 to 41 ) and nursing technicians 35.3 years ( $S D=11.5$; variation from 23 to 58 ). Regarding the time of professional experience, a 5.4 years mean $(S D=5.1$; variation from 4 months to 16 years) was found for nurses, and 13.8 years $(\mathrm{SD}=10$; variation from 3 to 28 ) for nursing technicians. Of 15 nurses, 11 underwent some kind of specialization course in the areas of Pediatrics, Neonatology, Emergency Care, Surgery Center, Intensive Care Unit and Teaching.

Researchers observed 121 rounds of medication, considering that 72 (59.5\%) were conducted by nurses and 49 (40.5\%) by nursing technicians. Interruptions occurred in 63 (52.1\%) rounds, for 127 interruptions in total. The preparation phase presented the most interruptions, 61 (48\%), and rounds conducted by nurses, $36(28.3 \%)$, and by nursing technicians, as shown in Table 1. The main interruption source was the nursing team, 48 (37.7\%), followed by self-interruption 29 (22.7\%) and multidisciplinary team 21 (16.5\%).

Table 1 - Frequency of interruption sources according to the phase of the medication process and professional category, São José do Rio Preto, São Paulo, Brazil, $2017 \mathrm{n}(\%)(\mathrm{N}=127)$

\begin{tabular}{|c|c|c|c|c|c|c|c|}
\hline \multirow[b]{2}{*}{ Fontes } & \multicolumn{2}{|c|}{ Preparation } & \multicolumn{2}{|c|}{ Administration } & \multicolumn{2}{|c|}{ Documentation } & \multirow{2}{*}{$\begin{array}{l}\text { Total } \\
\mathrm{N}(\%)\end{array}$} \\
\hline & $\begin{array}{c}E \\
\mathbf{n}(\%)\end{array}$ & $\begin{array}{c}\text { TE } \\
\mathbf{n}(\%)\end{array}$ & $\begin{array}{c}\mathbf{E} \\
\mathbf{n}(\%)\end{array}$ & $\begin{array}{c}\text { TE } \\
\mathbf{n}(\%)\end{array}$ & $\begin{array}{c}\mathbf{E} \\
\mathbf{n}(\%)\end{array}$ & $\begin{array}{c}\text { TE } \\
\mathbf{n}(\%)\end{array}$ & \\
\hline Patient & $3(2.4)$ & $3(2.4)$ & $0(0.0)$ & $0(0.0)$ & $1(0.8)$ & $0(0.0)$ & $7(5.6)$ \\
\hline Companion & $3(2.4)$ & $0(0.0)$ & $0(0.0)$ & $2(1.6)$ & $0(0.0)$ & $0(0.0)$ & $5(4.0)$ \\
\hline Nursing Team & $21(16.5)$ & $14(11.0)$ & $1(0.8)$ & $6(4.7)$ & $4(3.1)$ & $2(1.6)$ & $48(37.7)$ \\
\hline Multidis. Team & 13(10.2) & $6(4.7)$ & $0(0.0)$ & $1(0.8)$ & $1(0.8)$ & $0(0.0)$ & $21(16.5)$ \\
\hline Self-interruption & $14(11.0)$ & $9(7.0)$ & $4(3.1)$ & $1(0.8)$ & $0(0.0)$ & $1(0.8)$ & $29(22.7)$ \\
\hline Support Service & $3(2.4)$ & $2(1.6)$ & $0(0.0)$ & $1(0.8)$ & $0(0.0)$ & $0(0.0)$ & $6(4.8)$ \\
\hline Technology & $4(3.1)$ & $2(1.6)$ & $2(1.6)$ & $3(2.4)$ & $0(0.0)$ & $0(0.0)$ & $11(8.7)$ \\
\hline Total & $61(48.0)$ & $36(28.3)$ & $7(5.5)$ & $14(11.1)$ & $6(4.7)$ & $3(2.4)$ & $127(100)$ \\
\hline
\end{tabular}

Note: $N=$ Nurse; $N T=$ Nursing Technician; Multidis. Team=Multidisciplinary team.

Table 2 - Interruption causes - n(\%) - according to the phase of the medication process and professional category, São José do Rio Preto, São Paulo, Brazil, $2017(\mathrm{~N}=127)$

\begin{tabular}{|c|c|c|c|c|c|c|c|}
\hline \multirow[b]{2}{*}{ Causes } & \multicolumn{2}{|c|}{ Preparation } & \multicolumn{2}{|c|}{ Administration } & \multicolumn{2}{|c|}{ Documentation } & \multirow{2}{*}{$\begin{array}{l}\text { Total } \\
\text { N(\%) }\end{array}$} \\
\hline & $\begin{array}{c}\mathbf{N} \\
\mathbf{n}(\%)\end{array}$ & $\begin{array}{c}\text { NT } \\
\text { n(\%) }\end{array}$ & $\begin{array}{c}N \\
n(\%)\end{array}$ & $\begin{array}{c}\text { NT } \\
\mathbf{n}(\%)\end{array}$ & $\begin{array}{c}\mathbf{N} \\
n(\%)\end{array}$ & $\begin{array}{c}\text { NT } \\
\text { n(\%) }\end{array}$ & \\
\hline Unforeseen events & $2(1.6)$ & $3(2.4)$ & - & - & $1(0.8)$ & - & $6(4.8)$ \\
\hline Material supply & $6(4.7)$ & - & - & - & - & - & $6(4.7)$ \\
\hline Info. exchange & $26(20.5)$ & $14(11.0)$ & $4(3.1)$ & $4(3.1)$ & $4(3.1)$ & $2(1.6)$ & $54(42.4)$ \\
\hline Educ. Dem. & $2(1.6)$ & - & - & $2(1.6)$ & - & - & $4(3.2)$ \\
\hline Aid to Nurs. Team & $9(7.0)$ & $2(1.6)$ & - & $2(1.6)$ & $1(0.8)$ & - & $14(11.0)$ \\
\hline Alarm & $6(4.7)$ & $4(3.1)$ & $2(1.6)$ & $3(2.4)$ & $0(0.0)$ & - & $15(11.8)$ \\
\hline Conversations & 10(7.9) & $13(10.2)$ & $1(0.8)$ & $3(2.4)$ & - & $1(0.8)$ & $28(22.1)$ \\
\hline Total & $61(48.0)$ & $36(28.3)$ & $7(5.5)$ & $14(11.1)$ & $6(4.7)$ & $3(2.4)$ & $127(100)$ \\
\hline
\end{tabular}

Note: $N=$ Nurse; NT=Nursing Technician; Info. Exchange=Information Exchange; Educ. Dem.=Educational Demand; Aid to Nurs, Team=Aid to Nursing Team. 
Table 3 - Influence of interruptions in the mean time (in seconds) of the medication round, São José do Rio Preto, São Paulo, Brazil, 2017 ( $N=121)$

\begin{tabular}{|c|c|c|c|c|c|c|}
\hline \multirow{2}{*}{ Interruptions } & \multicolumn{2}{|c|}{$\begin{array}{l}\text { Preparation* } \\
\text { M(SD) }{ }^{+} \%\end{array}$} & \multicolumn{2}{|c|}{$\begin{array}{l}\text { Administration* } \\
\mathrm{M}(\mathrm{SD})^{+} \%\end{array}$} & \multicolumn{2}{|c|}{$\begin{array}{l}\text { Documentation* } \\
\text { M(SD) }{ }^{*} \%\end{array}$} \\
\hline & & & & & & \\
\hline Without & 374.4(309.7) & - & 452.8(333.8) & - & 453.9(338.4) & - \\
\hline With 1-3 & $575.5(338.1)$ & - & 535.7(345.4) & - & $592.5(232.2)$ & - \\
\hline With 4-7 & 615(236.8) & - & $540^{* *}$ & - & - & - \\
\hline \multicolumn{7}{|l|}{ Time Change } \\
\hline With 1-3 & 201.1 & 53.7 & 82.9 & 18.3 & 138.6 & 30.5 \\
\hline With 4-7 & 240.6 & 64.3 & 87.2 & 19.2 & - & - \\
\hline
\end{tabular}

Note: ${ }^{*} p<0.05 .{ }^{* *}$ Without $S D=$ unique occurrence. ${ }^{+} M-M e a n ; S D=S t a n d a r d$ Deviation.

Table 2 presents the main causes of interruption, the most frequent being: information exchange, 54 (42.4\%), conversations, $28(22.1 \%)$, and alarms, 15 (11.8\%). All occurred mainly during the medication preparation phase.

The mean time (in seconds) taken to accomplish rounds without and with interruptions was measured. The increase in the mean time ranged from 53.7 to $64.3 \%$ (preparation phase) and from 18.3 to $19.2 \%$ (administration phase) (Table 3).

\section{DISCUSSION}

This study shows important implications in nursing practice caused by interruptions during the medication process and reports some strategies that can be used to minimize them.

Interruptions during the clinical practice of nursing, especially during the administration of medication, interferes directly on patient safety, the quality of care and workload ${ }^{(4,20)}$. This study thus enabled a more detailed analysis of this occurrence.

This study found 63 (52.1\%) interruption episodes in 121 medication rounds, and a high frequency of this occurrence (1-7 times) during a single round, values greater than $36.1 \%$, and between one and three reported in pediatric ICUs ${ }^{(21)}$.

Pediatric $^{(21)}$ and neonatal ${ }^{(18)}$ units present some particularities regarding the fractionation of doses and the accuracy required in their quantity due to several potentially dangerous medications, and the low weight and age of patients; thus, requiring special attention from professionals during the medication rounds.

This investigation highlights the preparation phase as critical to the interruption of nurses (48\%) and nursing technicians (28.3\%), corroborating another study $(72.7 \%)^{(21)}$ conducted in a pediatric care inpatient unit. We must stress that when the professional is interrupted, his/her attention shifts to other demands ${ }^{(16)}$ and these distractions account for almost $50 \%$ of medication errors ${ }^{(22)}$.

Among the interruption sources, the nursing staff is described as the main agent ${ }^{(4,17,21)}$, as was also found in this study $(37.7 \%)$. Self-interruptions (22.7\%) and those motivated by the multidisciplinary team, 21 (16.5\%), were also observed. Self-interruptions occur when the professional decides to discontinue his/her task to perform another activity, which appears as an important source in other studies ${ }^{(16,23)}$. Self-interruption is considered alarming ${ }^{(13,16)}$, accounting for $32.1 \%$ of the interruptions observed ${ }^{(16)}$. This is a preventable event and requires awareness and better care planning from the team.
Information exchanges (42.4\%), parallel conversations $(22.1 \%)$ and responding to alarms $(11.8 \%)$ were the main causes of disruption. Information exchange was considered as any observations regarding the patient transferred from person to person due to necessary prescription changes regarding the dose, stoppage of medicines or inclusion of a new therapy. We can infer that these daily adjustments account for many of these communications ${ }^{(21)}$.

On the other hand, some interruptions must be avoided such as parallel conversations about personal interest matters outside the context of work ${ }^{(16)}$. Nurses recognize that interruptions occur during the various actions conducted and have negative influence in the care process, affecting both the patient and professional's safety ${ }^{(17)}$.

Although there are initiatives to mitigate interruptions, the potential for errors still exists ${ }^{(24)}$. The implementation of interventions showed a significant reduction in the number of interruptions during the medication process, of almost $87 \%^{(25)}$. Some of the strategies adopted by international health institutions include the use of a vest with the warning "Please, do not interrupt me" when the professional is preparing medications ${ }^{(26)}$ and the provision of a secluded place without distractions and interruption sources for the preparation of medications ${ }^{(27-28)}$.

Investments for behavioral changes also include: the training of professionals, providing visible symbols and information leaflets for patients and their families, thus involving them in interruption prevention the campaign ${ }^{(7)}$. On the other hand, having to stop a primary task at the expense of another of higher priority or multitasking mediated by interruptions that support the resumption of the initial activity, or the blocking of the interruption to keep focus on the main task are fundamental discussions to be addressed with the teams when planning interventions ${ }^{(29)}$.

Another important aspect related to interruptions regards the impact on the workload of nursing. This study allowed us to identify that the time spent by the professionals to prepare the medications increased by $53.7 \%$ if one to three interruptions occurred, and by $64.3 \%$ if four to seven interruptions occurred. This increase in time also occurred during the medication administration phase, 18.3\% (1-3 interruptions) and $19.3 \%$ (4-7 interruptions), and in the documentation phase in $30.5 \%$ (1-3 interruptions). Therefore, interrupted activities take longer to be accomplished $^{(17-18)}$, generating work overload on the nursing team.

The difference in time between activities conducted without interruptions and those in which the professional is interrupted has been shown to be significant ${ }^{(30)}$, compromising, on average, $9.4 \%$ of the working time of the nursing team ${ }^{(31)}$. Studies present evidence for an interruption occurring every minute ${ }^{(32)}$ or variations ranging from six to 26 interruptions per hour $r^{(7,23,31,33-34)}$. A study identified that the interruption of the medication process can last, on average, 32.7 seconds $^{(33)}$, and this practice becomes even more worrisome when considering that only $22 \%$ of 488 interruptions observed in another study were related to patient care ${ }^{(34)}$.

In addition to the attention, we must highlight the time spent by nursing professionals in the preparation and administration of drugs ${ }^{(35)}$. The care provided can be compromised when the workload increases ${ }^{(36)}$, with the omission of care and greater risks of adverse events ${ }^{(35)}$ and, consequently, having impacts on patient 
satisfaction. This is the second most common factor among the causes for medication errors ${ }^{(20)}$ that affect the risk of death ${ }^{(37)}$.

\section{Study limitations}

The concomitant evaluation of multiple processes, the possible changes in the behavior of professionals, and the performance of a single observer can be considered as limitations. Moreover, the night shift could not be reviewed because the observer had no availability, thus making the comparison between all teams impossible.

\section{Contributions to the field of nursing, health or public policy}

Although restricted to a single practice environment (NICU), the contribution of this study stems from its extensive observation of the process when compared to the literature found; furthermore, its specificity on the characteristics of interruptions, particularly regarding how long they took and their impact on nursing workload, also represent a contribution. This study thus serves as an instrument for nurses, administrators, researchers and educators who search for improved practices in medication care, and in the investigation of other processes are also interrupted.

\section{CONCLUSION}

The more in-depth analysis of the interruption process allowed the identification of its main sources (nursing team) and causes (information exchange about care) during the medication process conducted by the nursing team of a NICU, corroborating with evidence that this risk situation is common in professional practice.

The results highlight medication rounds generating greater workload for the team. Thus, the construction of a suitable environment for the occurrence of minimum interruptions during this process shall provide better safety and quality in the management of care.

\section{ACKNOWLEDGEMENTS}

We would like to thank the research group "Gestão de Serviços de Saúde e de Enfermagem" (GESTSAÚDE) of the School of Medicine of São José do Rio Preto, São José do Rio Preto, SP, Brazil.

\section{REFERENCES}

1. Trbovich P, Prakash V, Stewart J, Trip K, Savage P. Interruptions during the delivery of high-risk medications. J Nurs Adm [Internet]. 2010 [cited 2018 Mar 7];40(5):211-8. Available from: https://www.ncbi.nlm.nih.gov/pubmed/20431455

2. D'Antonio S, Bagnasco A, Bonetti L, Sasso L. Observational study on interruptions during nurses work in two surgical wards of a hospital in Liguria. Prof Inferm [Internet]. 2014 [cited 2017 Feb 12];67(4):211-8. Available from: https://www.ncbi.nlm.nih.gov/pubmed/25837476

3. Hayes C, Jackson D, Davidson PM, Power T. Medication errors in hospitals: a literature review of disruptions to nursing practice during medication administration. J Clin Nurs [Internet]. 2015 [cited 2017 Feb 4];24(21-22):3063-76. Available from: https://pdfs.semanticscholar. org/d307/1 ef2834821b57acc41b57c39ff965fafb405.pdf

4. Smeulers M, Hoekstra M, Van Dijk E, Overkamp F, Vermeulen H. Interruptions during hospital nurses' medication administration rounds. Nurs Rep [Internet]. 2013 [cited 2017 Mar 14];3(1):18-23. Available from: http://www.pagepressjournals.org/index.php/nursing/article/view/ nursrep.2013.e4

5. Cornell P, Herrin-Griffith DMSN, Keim C, Petschonek S, Sanders AM, D'Mello S, et al. Transforming Nursing Workflow, part 1: the chaotic nature of nurse activities. J Nurs Adm [Internet]. 2010 [cited 2017 May 9];40(9):366-73. Available from: http://journals.Iww.com/jonajournal/ Abstract/2010/09000/Transforming_Nursing_Workflow,_Part_1_The_Chaotic.6.aspx

6. Sasangohar F, Donmez B, Easty A, Storey H, Trobovich P. Interruptions experienced by cardiovascular intensive care unit nurses: an observational study. J Crit Care [Internet]. 2014 [cited 2017 Jun 20];29(5):848-53. Available from: http://acelab.tamu.edu/wp-content/ uploads/sites/23/2016/10/1-s2.0-S0883944114002081-main.pdf

7. Relihan $\mathrm{E}, \mathrm{O}^{\prime} \mathrm{Brien} \mathrm{V}, \mathrm{O}^{\prime} \mathrm{Hara} \mathrm{S}$, Silke $\mathrm{B}$. The impact of a set of interventions to reduce interruptions and distractions to nurses during medication administration. BMJ Qual Saf [Internet].2010 [cited 2017 Jan 10]; 19(5): 1-6. Available from: https://pdfs.semanticscholar.org/ dbcc/b7beb53823a9d054005aef6ee5ed5b1184c6.pdf

8. Sorensen EE, Brahe L. Interruptions in clinical nursing practice. J Clin Nurs [Internet]. 2014 [cited 2017 Jun 22];23(9-10):1274-82. Available from: https://onlinelibrary.wiley.com/doi/full/10.1111/jocn.12329

9. Biron AD, Tremblay ML, Loiselle CG. Characteristics of work interruptions during medication administration. J Nurs Scholarsh [Internet]. 2009 [cited 2016 Dec 5];41(4),330-36. Available from: https://sigmapubs.onlinelibrary.wiley.com/doi/full/10.1111/j.1547-5069.2009.01300

10. Hall LM, Pedersen C, Fairlei L. Losing the moment: understanding interruptions to nurses' work. J Nurs Adm [Internet]. 2010 [cited 2017 Jan 12];40(4):169-76. Available from: http://www.ncbi.nlm.nih.gov/pubmed/20305462

11. Westbrook Jl, Duffield C, Li L, Creswick NJ. How much time do nurses have for patients? a longitudinal study quantifying hospital nurses' patterns of task time distribution and interactions with health professionals. BMC Health Serv Res [Internet]. 2011 [cited 2017 Mar 18];11:112. Available from: https://bmchealthservres.biomedcentral.com/articles/10.1186/1472-6963-11-319

12. Raban MZ, Westbrook Jl. Are interventions to reduce interruptions and errors during medication administration effective? a systematic review. BMJ Qual Saf [Internet]. 2014 [cited 2017 Mar 17];23(5):414-21. Available from: http://qualitysafety.bmj.com/content/23/5/414

13. Monteiro C, Avelar AFM, Pedreira MDLG. Interruptions of nurses' activities and patient safety: an integrative literature review. Rev Latino-Am Enfermagem [Internet]. 2015 [cited 2017 Jan 20];23(1):169-79. Available from: http://www.scielo.br/pdf/rlae/ 


\section{v23n1/0104-1169-rlae-23-01-00169.pdf}

14. Aydon $\mathrm{L}$, Hauck Y, Zimmer M, Murdoch J. Factors influencing a nurse's decision to question medication administration in a neonatal clinical care unit. J Clin Nurs [Internet]. 2016 [cited 2017 Nov 18];25:2468-77. Available from: https://onlinelibrary.wiley.com/doi/full/10.1111/jocn.13277

15. Beyea SC. Distractions, interruptions, and patient safety. AORN J [Internet]. 2007 [cited 2017 July 14];86(1):109-12. Available from: http:// www.interruptions.net/literature/Beyea-AORN07-a.pdf

16. Prates DO, Silva AEBC. Interruptions of activities experienced by nursing professionals in an intensive care unit. Rev Latino-Am Enfermagem [Internet]. 2016 [cited 2017 Jan 13];24:1-9. Available from: http://www.scielo.br/pdf/rlae/v24/pt_0104-1169-rlae-24-02802.pdf

17. Sassaki RL, Perroca ML. Interruptions and their effects on the dynamics of the nursing work. Rev Gaucha Enferm [Internet]. 2017 [cited 2017 Feb 13];38(2):1-8. Available from: http://www.scielo.br/pdf/rgenf/v38n2/0102-6933-rgenf-1983-144720170267284.pdf

18. Lanzillotti LDS, Seta MHD, Andrade CLTD, Mendes Jr WV. Adverse events and other incidents in neonatal intensive care units. Cien Saude Colet [Internet]. 2015 [cited 2017 Jun 12];20(3):937-46. Available from: https://doi.org/10.1590/1413-81232015203.16912013

19. Barnes RM. Estudo de tempos e movimentos: projeto e medida de trabalho. São Paulo: Edgard Blucher; 2001.

20. Tang Fl, Sheu SJ, Yu S, Wei IL, Chen CH. Nurses relate the contributing factors involved in medication errors. J Clin Nurs [Internet]. 2007 [cited 2017 Nov 10];16(3):447-57. Available from: https://pdfs.semanticscholar.org/dcbe/3c11 bc5f9432711aae82a76bee65ec4469a6.pdf

21. Özkan S, Kocaman G, Öztürk C. Interruptions during pediatric medication preparation and administration. J Pediatr Res [Internet]. 2016 [cited 2017 Nov 10];3(2):104. Available from: http://cms.galenos.com.tr/Uploads/Article_11971/104-108.pdf

22. Feil M. Distractions and their impact on patient safety. Patient Saf Advis [Internet]. 2013 [cited 2017 Mar 14];10(1):1-10. Available from: http://patientsafety.pa.gov/ADVISORIES/Pages/201303_01.aspx

23. Brixey JJ, Tang Z, Robinson DJ, Johnson CW, Johnson TR, Turley JP, et al. Interruptions in a level one trauma center: a case study. Int J Med Inform [Internet]. 2008 [cited 2017 Jun 12];77(4):235-41. Available from: https://www.ncbi.nlm.nih.gov/pmc/articles/PMC2670398/pdf/nihms-43310.pdf

24. Kalisch BJ, Aebersold M. Interruptions and multitasking in nursing care. Jt Comm J Qual Patient Saf [Internet]. 2010 [cited 2017 Nov 4];36(3):126-32. Available from: http://www.jointcommissionjournal.com/article/S1553-7250(10)36021-1/fulltext

25. Pape TM. Applying airline safety practices to medication administration. Medsurg Nurs [Internet]. 2003 [cited 2018 Jul 23];12:77-93. Available from: https://www.ncbi.nlm.nih.gov/pubmed/12736927

26. Currie L. Reducing interruptions during medication administration: the white vest study. J Res Nurs [Internet]. 2014 [cited 2017 Jan 10];19(3):262-63. Available from: http://journals.sagepub.com/doi/abs/10.1177/17449871113484737

27. Anthony K, Wiencek C, Bauer C, Daly B, Anthony MK. No interruptions please: impact of a no interruption zone on medication safety in intensive care units. Crit Care Nurse [Internet]. 2010 [cited 2018 Jul 22];30(3):21-9. Available from: https://www.ncbi.nlm.nih.gov/pubmed/20067939

28. Tomieto M, Sartor A, Mazzocoli E, Palese A. Paradoxical effects of a hospital-based, multi-intervention programme aimed at reducing medication round interruptions. J Nurs Manag [Internet]. 2012 [cited 2018 Jul 23];20(3):335-43. Available from: https://www.ncbi.nlm.nih. gov/pubmed/22519611

29. Colligan L, Bass EJ. Interruption handling strategies during pediatric medication administration. BMJ Qual Saf [Internet]. 2012 [cited 2018 Jul 23];21(11):912-7. Available from: https://www.ncbi.nlm.nih.gov/pubmed/22791692

30. Johnson KD, Gillespie GL, Vance K. Effects of interruptions on triage process in emergency department: a prospective, observational study. J Nurs Care Qual [Internet]. 2018 [cited 2018 Jul 18]. Available from: https://www.ncbi.nlm.nih.gov/pubmed/29319593

31. Prates DO, Silva AEBC. Interrupções de atividades vivenciadas por profissionais de enfermagem em unidade de terapia intensiva. Rev Latino-Am Enfermagem [Internet]. 2016 [cited 2018 Jul 17];24:1-9. Available from: http://www.redalyc.org/pdf/2814/281449727031.pdf

32. Spooner AJ, Corley A, Chaboyer W, Hammond NE, Fraser JF. Measurement of the frequency and source of interruptions occurring during bedside nursing handover in the intensive care unit: an observational study. Aus Crit Care [Internet]. 2015 [cited 2018 Jul17];28(1):19-23. Available from: https://www.sciencedirect.com/science/article/pii/S1036731414000319

33. Dante A, Andrigo I, Barone F, Rossella B, Antonio DC, Michela N, et al. Occurrence and duration of interruptions during nurses' work in surgical wards: findings from a multicenter observational study. J Nurs Care Qual [Internet]. 2016 [cited 2017 Mar 3];31(2):174-82. Available from: http://journals.Iww.com/jncqjournal/Abstract/2016/04000/Occurrence_and_Duration_of_Interruptions_During.12.aspx

34. Johnson KD, Motavalli M, Gray D, Kuehn C. Causes and occurrences of interruptions during ED triage. J Emerg Nurs [Internet]. 2014 [cited 2018 Jul 17];40(5),434-39. Available from: https://www.sciencedirect.com/science/article/pii/S0099176713004273

35. Magalhães AMM, Dall'Agnol CM, Marck PB. Nursing workload and patient safety: a mixed method study with an ecological restorative approach. Rev Latino-Am Enfermagem [Internet]. 2013 [cited 2017 May 13];21:146-54. Available from: http://www.journals.usp.br/rlae/ article/view/52937/56932

36. Umansky J, Rantanen E. Workload in nursing. Proceedings of the Human Factors and Ergonomics Society Annual Meeting[Internet]. 2016 Sept 15; Los Angeles, USA. Santa Monica: Sage; 2016[cited 2017 May 13]. p. 551-55. Available from: http://journals.sagepub.com/doi/ pdf/10.1177/1541931213601127

37. Novaretti MCZ, Santos EV, Quitério LM, Daud-Gallotti RM. Nursing workload and occurrence of incidents and adverse events in ICU patients. Rev Bras Enferm [Internet]. 2014 [cited 2017 Jan 13];67(5):692-99. Available from: http://www.scielo.br/pdf/reeusp/v50n4/0080-6234reeusp-50-04-0683.pdf 